\title{
Proteomic and Physiological Indices-Based Selection of Broadly Diverse Sugarcane (Saccharum Spp) New Genotypes
}

\author{
Nagat A. Mousa 1, E.S.R. Salem² and M.Z. Attallah ${ }^{2}$
}

\begin{abstract}
Distantly-related 42 (S1-S42) genotypes of sugarcane (Saccharum spp) were selected phenotypically from new genotypes generated from seeds of an open-pollinated parent, EH 26-2 (pedigree, LCP 81-10 X cp76-331) unfortunately, at the age of 100-days-old, two of the selected genotypes, namely S29 and S36, could not adapt to environmental conditions and were excluded from consideration. Proteomic analysis was carried out involving quantitative analysis of total soluble protein of leaf tissue extracts at five month-old plants and electrophoresis separation of proteins. The analysis showed significant differences among genotypes, in the total soluble protein content which ranged from $4.42 \pm$ 0.22 to $2.73 \pm 0.06 \mathrm{mg} / \mathrm{g}$ tissues, which were observed in genotype $\mathrm{S37}$ and $\mathrm{S28}$, respectively. Despite the results of total protein analysis of sugarcane leaf tissues appeared to vary among genotypes, it did not suggest evidence that protein content alone was a reliable marker for identifying genotypes. The analysis of protein by SDS-PAGE revealed clear differences in intensity and number of bands amongst genotypes. Furthermore, phylogenetic analysis of the 40 genotypes elucidated by electrophoresis, showed a wide range of total protein polymorphic variants. At least four (4) distinguishable clusters of genotypes were identified, amongst which was a cluster containing genotypes S17, S18, S25, S26 and S27; which were most distantly-related to the sub-cluster containing S35, S37, S42, S38, S39 and S40. Moreover, the physiological profiles of these genotypes were assessed at the age of 180 days, the leaf physiological characters of the remaining eleven potential sugarcane genotypes, relevant to plant response of drought, were evaluated. The studied parameters; included stomata length, width and number, epicuticular wax, relative leaf water content, chlorophyll content, peroxidase activity and proline content revealed that the distantly-related genotypes S25 and S40 which could be potential as future varieties in addition, the eleven genotypes may be useful parents in future sugarcane breeding programs in crosses to identify hybrids with high specific combining ability.
\end{abstract}

Keywords: clonal identification, drought, electrophoresis, germplasm maintenance, isozymes, Saccharum spp, sugarcane.

${ }^{1}$ Breeding and Genetics Department, Sugar Crops Research Institute, Agriculture Research Centre

${ }^{2}$ Physiology and Chemistry Department, Sugar Crops Research Institute, Agriculture Research Centre

Received October 31, 2016, Accepted December 7, 2016

\section{INTRODUCTION}

In Egypt, the Sugar Crops Research Institute has invested much effort over the past three decades to generate new varieties of sugarcane with high sugar accumulation and resistance to pests and diseases. This effort began with Allam's work (Allam et al., 1977) and is being achieved through breeding, selection and evaluation of hybrids, based mainly on broadening the genetic base through interspecific hybridization of cultivars. However, the progress has been affected by the limited genetic diversity among cultivars currently available. As a result, efforts of generating variability through open pollination would achieve genetic gains in breeding programs. This approach has allowed sugarcane breeders worldwide for accomplishing a great success (Srivastava, 1993).

Molecular markers based on protein and enzyme polymorphism among genotypes are of the most popular selection tools in discriminating among genotypes and hold potentials utility in sugarcane breeding (Ramagopal, 1990). Synthesis of proteins is coded for by genes in genotypes; hence proteins are valuable source of genetic markers in sugarcane and could be useful to identify specific genotype and stages of its development (Menéndez et al., 1994 and Glaszmann, 1989).

Many recent proteomic studies have been performed on various species under different abiotic stresses, but there have been only a few proteomic studies in sugarcane (Sugiharto et al., 2002 and Amalraj et al., 2010). Disc-polyacrylamide gel electrophoresis (DiscPAGE) was used to separate native soluble proteins by Davis (1964) and Wagih et al. (2005). The general characterization of the proteome to identify the largest possible number of proteins or the differentially expressed proteins between genotypes is a commonly used procedure in proteomics (Park, 2004).

In addition, certain sugarcane leaf physiological characters are closely related to the characterization of genotypes. Low density of stomata, thick cuticle, short and narrow leaves would be selection criteria in screening genotypes for drought tolerance (Yadav and Prasad, 1988). Routine methodologies were described 
for epicuticular wax, stomata characters (Rai, 1999) leaf water content (Karakas et al., 1997), chlorophyll content and proline content (Jagtap et al., 1988).

Therefore, the investigation aimed at using some leaf proteomic and physiological analysis of some new genotypes of sugarcane for identification and selection of the distantly-related genotypes as potential genotypes and for use in future breeding programs.

\section{MATERIALS AND METHODS}

\section{Plant material}

Seeds were planted at 24/8/2014 in greenhouse of Sabahia Research Station, Alexandria, Sugar Crops Research Institute (SCRI). Leaf tissue samples were obtained from 150-days-old sugarcane plants of 40 new genotypes (S1-S42), where at the age of 100-days-old, two of the selected genotypes, namely S29 and S36, could not adapt to environmental conditions and were excluded from consideration, generated from seeds of open-pollination of the parent EH 26-2(pedigree, LCP 81$10 \mathrm{X}$ cp76-331) known to be vigorous and drought tolerant (Badawy et al., 2006). Samples were collected from sets in grown greenhouse, grown in the absence of water shortage, salinity, or other intended stresses and stored in $-20^{\circ} \mathrm{C}$ freezer prior using for protein profiling within days from collection. After one month fresh leaves of the eleven selected genotypes were collected for studying leaf physiological characteristics to assess plant response to drought.

\section{Extraction of Whole Protein from Sugarcane Leaves:}

Total soluble proteins of sugarcane frozen leaves were extracted as described by Shewry et al. (1996). Firstly, $0.5 \mathrm{~g}$ of fresh sugarcane leaves was grinded into powder in liquid nitrogen. Grounded samples were mixed in $200 \mu$ l lyses buffer ( $84 \mathrm{mM}$ citric acid, $32 \mathrm{mM}$ $\mathrm{Na}_{2} \mathrm{HPO}_{4}, 15 \mathrm{mM} \beta$-mercaptoethanol and $\mathrm{pH}$ was set to 8.2 ). Secondly, the mixed liquid was precipitated on ice for $30 \mathrm{~min}$ and centrifugation at $10,000 \mathrm{~g}$ for $10 \mathrm{~min}$ at $4{ }^{\circ} \mathrm{C}$ and then the supernatant was discarded and the pellet was re-suspended with cold acetone containing $0.07 \% \beta$-mercaptoethanol and kept overnight at $-20{ }^{\circ} \mathrm{C}$. Thirdly, after centrifugation for $30 \mathrm{~min}$ with $10,000 \mathrm{~g}$, the pellet was resuspended with $80 \%$ acetone and kept for $1 \mathrm{~h}$ at $-20{ }^{\circ} \mathrm{C}$, and then it was centrifuged again. Finally, the pellet was dried into powder by vacuum drying at low temperature and stored at $-80^{\circ} \mathrm{C}$ until use. Pellets were suspended in rehydration buffer containing $7 \mathrm{M}$ urea, $2 \mathrm{M}$ thiourea, 2\% (w/v) CHAPS, $2 \mathrm{mM}$ DTT, $0.8 \%(\mathrm{w} / \mathrm{v})$ IPG buffer and $0.2 \%$ bromophenol blue.

The supernatant used for 1-DE analysis. Total protein content was measured according to the method developed by Bradford (1976) using bovine serum albumin as the standard, Sodium dodecyl sulphate polyacrylamide gel electrophoresis (SDS- PAGE) was carried out using the discontinuous buffer system as described by Sambrook et al. (1989), with the gel concentration of $12.0 \%$ samples were then denatured by heating at $100{ }^{\circ} \mathrm{C}$ for $3 \mathrm{~min}$ followed by immediate cooling on ice. Then, samples were loaded into the gel and electrophoresis was carried out for 3-h at $80 \mathrm{~V}$ across the polyacrylamide gel using consort power supply (Biometra, USA) and mini protein cell (Bio-Rad, USA) containing running buffer. When, SDS-PAGE finished, the gel was taken out and stained in $50 \mathrm{ml}$ of staining solution consisting of $0.1 \%$ coomassie blue R250 as described by Hames and Rickwood (1990). Protein pattern bands were measured used Hyper PAGE II pre-stained protein marker (BIOLINE, United Kingdom).

Quantification of soluble protein contents: Total soluble protein extracts concentration was determined by a colorimetric method using a commercially available reagent (Bio-Rad protein assay dye reagent), as described by Bradford (1976). Tubes containing 100 $\mu \mathrm{l}$ aliquots of a standard known concentrations of Bovine Serum Albumin (BSA; $0.156 \mathrm{mg} \mathrm{l-1}$ to $10 \mathrm{mg} \mathrm{l-}$ 1 in $0.15 \mathrm{M} \mathrm{NaCl}$ ), were prepared. Blank tubes containing $100 \mu \mathrm{l}$ of $0.15 \mathrm{M} \mathrm{NaCl}$ were also prepared. One ml Coomassie Brilliant Blue solution was added to each tube and vortexed. The reactions were left at room temperature for $2 \mathrm{~min}$. The absorbance at wavelength of $595 \mathrm{~nm}$ was determined against the blank and the standard curve of absorbance versus protein concentration plotted. The proteins concentration of the extracts was determined from the standard curve, using a Unicam 8620 UV/VIS (USA) Spectrophotometer.

\section{Assessment of leaf physiological parameters}

Leaf physiological parameters including stomata length, width and number, epicuticular wax, relative leaf water content (RWC), chlorophyll content, peroxidase activity and proline content, were measured in the eleven selected genotypes, including no., S17, S18, S25,S26, S27, S35, S37, S38, S39, S40 and S42 at the age of 180-days.

Stomata characteristics were measured following nail paint peeling technique as described by Capellades et al. (1990).

Epicuticular wax was measured using a micrometer as described by Rai (1999).

Leaf relative water content (RWC) was determined by excising $100 \mathrm{~mm}^{2}$ of leaf, weighed, and then reweighted after floated on distilled water for 24 hours, oven drying at $80^{\circ} \mathrm{C}$ to get the dry weight. RWC $=(\mathrm{FW}$ $-\mathrm{DW}) .(\mathrm{TW}-\mathrm{DW})$ where $\mathrm{FW}=$ leaf fresh weight, $\mathrm{DW}$ 
$=$ dry weight and $\mathrm{TW}=$ turgid weight $(\mathrm{Mu}-\mathrm{Qing}$ and Ru-Kai, 1998).

Chlorophyll content was essentially carried out using a modified method used by Wagih et al. (2005). Under deem light, $0.25 \mathrm{~g}$ of leaf tissue were grinded with 20 $\mathrm{ml}$ of $80 \%$ acetone, $0.1 \mathrm{~g}$ (approx.) of $\mathrm{CaCO} 3$ to neutralize acid in the cell and to prevent loss of $\mathrm{Mg}$ from the chlorophyll centre in a pre-cooled mortar, in the presence of small quantity of washed sand. The homogenate was centrifuge at $10,000 \mathrm{~g}$ for 10 minutes. The supernatants were adjusted to $50 \mathrm{ml}$ with acetone. Optical density was determined at $663 \mathrm{~nm}$ (absorption peak of Chlorophyll a) and $645 \mathrm{~nm}$ (absorption peak of Chlorophyll b) in the spectrophotometer, using acetone $80 \%$ as a blank. The concentrations of chlorophyll were calculated by the following formula: [(Chlorophyll $\mathrm{a}=12.7 \times \mathrm{A} 663-2.69 \times \mathrm{A}$ 645)], [(Chlorophyll $\mathrm{b}=$ $25.8 \times \mathrm{A} 645-4.68 \times \mathrm{A} 663)$ ]; and [(Chlorophyll $\mathrm{a}+\mathrm{b}$ $=20.21 \times \mathrm{A} 645+8.02 \times \mathrm{A}$ 663)]. Content of chlorophyll, $\mathrm{mg} / \mathrm{g}$ fresh weight $=[(\mathrm{C}-\mathrm{x} \mathrm{mgL}-1 \mathrm{x}$ total amount of extract (ml) $\mathrm{x}$ dilution) / (gram fresh weight of sample $\mathrm{x}$ 1000)], where $\mathrm{C}-\mathrm{x}$ represents the concentration of $\mathrm{Ca}, \mathrm{Cb}$ and $\mathrm{Ca}+\mathrm{b}$, respectively.

Peroxidase activity was determined by the Zymoblot technique essentially as described by Wagih and Wagih (1997). One gram of leaf sample was ground in a mortar with Tris-buffered saline $\mathrm{pH} 7.4$ (TBS; $25 \mathrm{mM}$ Tris$\mathrm{HCl}$, consists of $8 \mathrm{~g} \mathrm{~L}-1 \mathrm{NaCl}$; $0.2 \mathrm{~g} \mathrm{~L} \mathrm{KCl}$; Tris $3 \mathrm{~g} / \mathrm{L}$ and Phenol-red $0.015 \mathrm{~g} / \mathrm{L}$ ) at a ratio of $1: 5 \mathrm{w} / \mathrm{v}$. The crude tissue extract was centrifuge at $10,000 \mathrm{~g}$ for 10 min and the supernatants were recovered and tested for enzyme activity. Aliquots of $2 \mu 1$ of clarified extracts were blotted onto nitrocellulose membrane. Blots were air-dried, then marinated in a suitable enzyme-reaction mixture. Instead of applying 1-5 $\mu \mathrm{l}$ clarified extracts to nitrocellulose membrane, $20 \mu \mathrm{l}$ clarified extracts were applied to the membrane; which was air-dried, then marinated in a reaction mixture contained $5 \mathrm{ml}$ TBS buffer plus $1 \mathrm{ml}$ of substrate mix (3 mg of 4-chloro-1- napthol in $1 \mathrm{ml}$ of methanol) plus $20 \mu \mathrm{l}$ of $3 \%$ hydrogen peroxide, shacked gently under light at room temperature until a color reaction was developed. Result was code visually as a percentage of color density develops on the blot after incubation. The color density was scored as percentage, compared to the control dense reaction.

Proline content was determined as $\mathrm{mg} / \mathrm{g}$ fresh weight of leaf, according to Bates et al. (1973).

\section{Statistical analysis}

The quantitative amounts of total protein were statistically analyzed using Duncan's Multiple Range Test with three replications. Phylogenetic trees were constructed using PAST, Version 3.08, 2015. The physiological traits were analyzed by ANOVA, LSD, simple multiple linear correlation using Statistix 1.0 for Windows software (Analytical Software, Tallahassee FL).

\section{RESULTS AND DISCUSSION}

\section{Assessment of soluble protein content}

Assessment of soluble protein content of leaf tissues of 40 new genotypes grown in the absence of any intended stress is presented in Figure 1. The results showed significant differences $(p<0.05)$ amongst genotypes, labeled (a), (b) and (c). The values of total soluble protein content ranged from $4.42 \pm 0.22$ to 2.73 $\pm 0.06 \mathrm{mg} / \mathrm{g}$ tissues. The maximum value was observed in genotype S37, which did not differ significantly $(p>0.05)$ from 24 other genotypes labeled (a). The minimum value was observed in genotype S28, that did not differ significantly $(\mathrm{p}>0.05)$ from three (3) other genotypes labeled (c). Between them, a group of eleven (11) genotypes labeled (b) did not differ significantly $(p>0.05)$ from one another. The major disadvantages of proteomic markers are that they may be liited in number and are influenced by environmental stages of the plant.

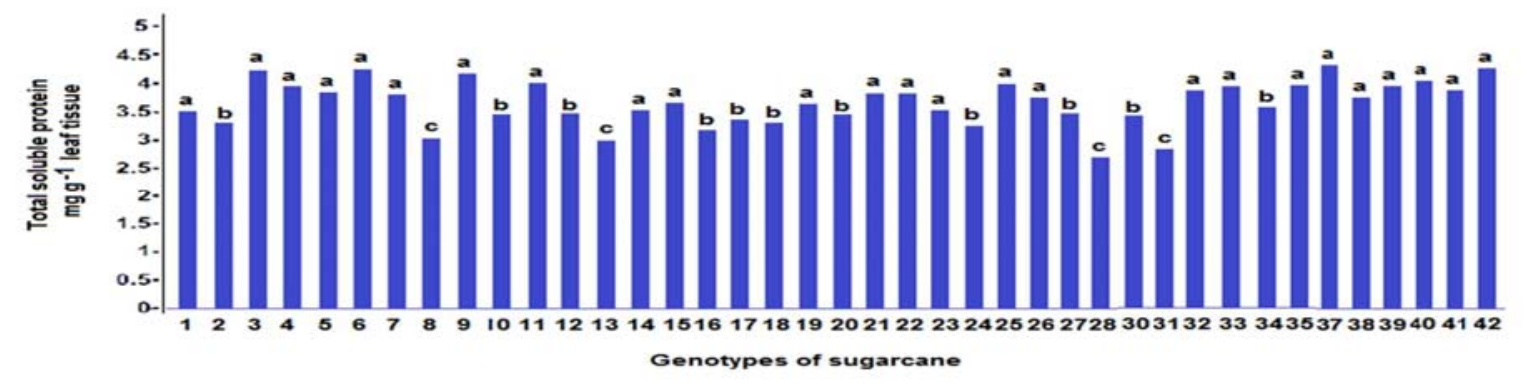

Figure 1. Differential accumulation of total protein content $(\mathrm{mg} / \mathrm{g})$ in leaf tissues of $40 \mathrm{new}$ genotypes of sugarcane during formative phase of growth (150-days-old sugarcane). The letters $a, b$ and $c$ represent the significance of means (three replications) difference according to Duncan's Multiple Range Test. 
Analysis of soluble proteins by electrophoresis

Analysis of soluble proteins of sugarcane leaf tissues extracted at $\mathrm{pH}(8.3)$, separated by SDS-PAGE gels following coomassie blue staining shown in Figure 2, revealed at least four (4) protein bands, and a maximum of thirteen (13) bands. Comparison of the protein profiles revealed clear differences in intensity and number of bands amongst genotypes. These results suggest a mean of differentiating among sugarcane genotypes. Separation of proteins by electrophoresis is advantageous as it gives overview of tissue by molecular mass.
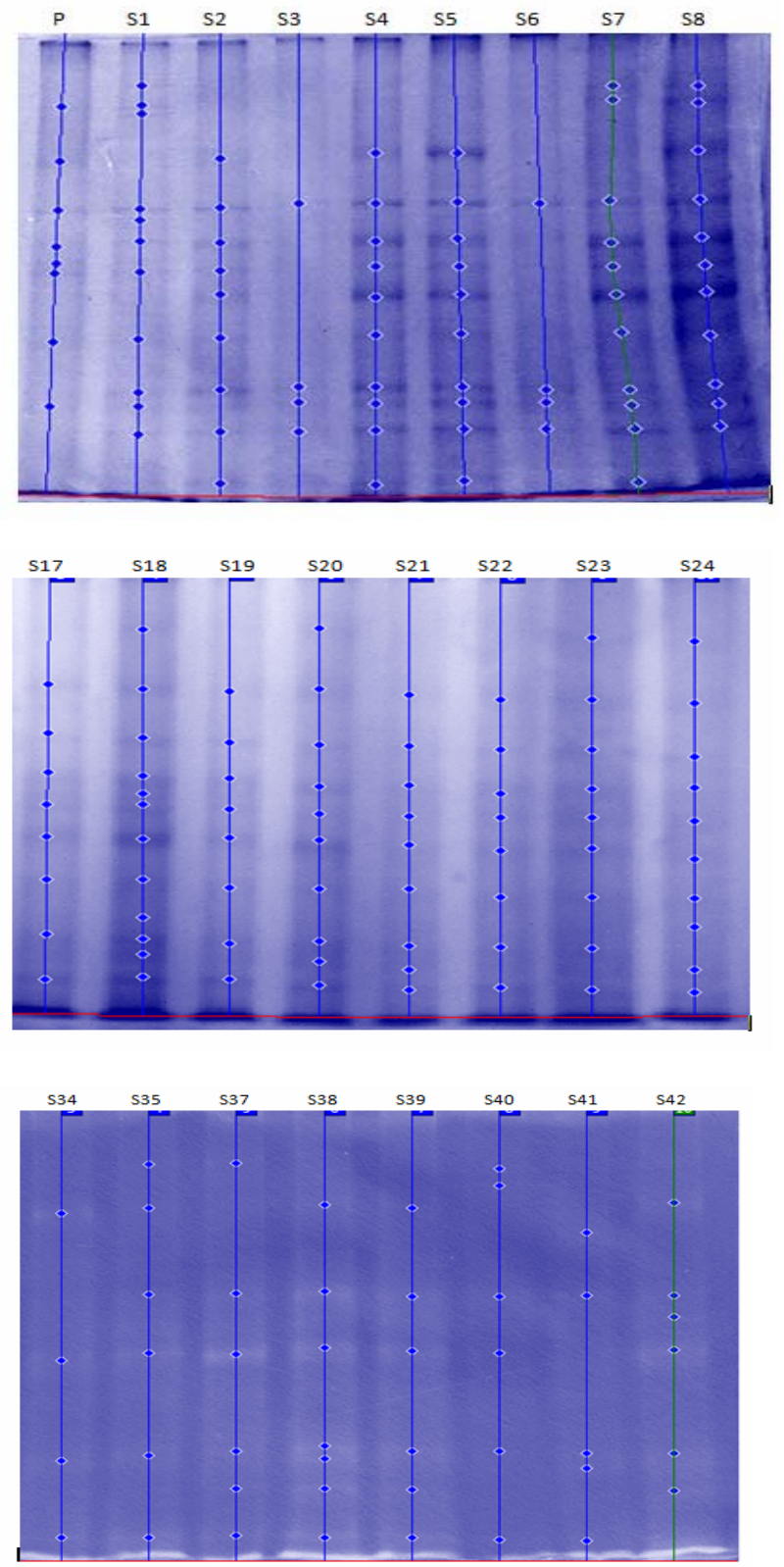

Differential protein expression of genotypes appeared, not only in the expression capacity of the same protein, but also in totally absent proteins. Park (2004) stated that the general characterization of the proteome to identify the largest possible number of proteins or the differentially expressed proteins between genotypes is a commonly used procedure in proteomics. The protein expression pattern was contrasting, suggesting that the differentially expressed proteins may be related to different performance of genotypes under the growing environment.
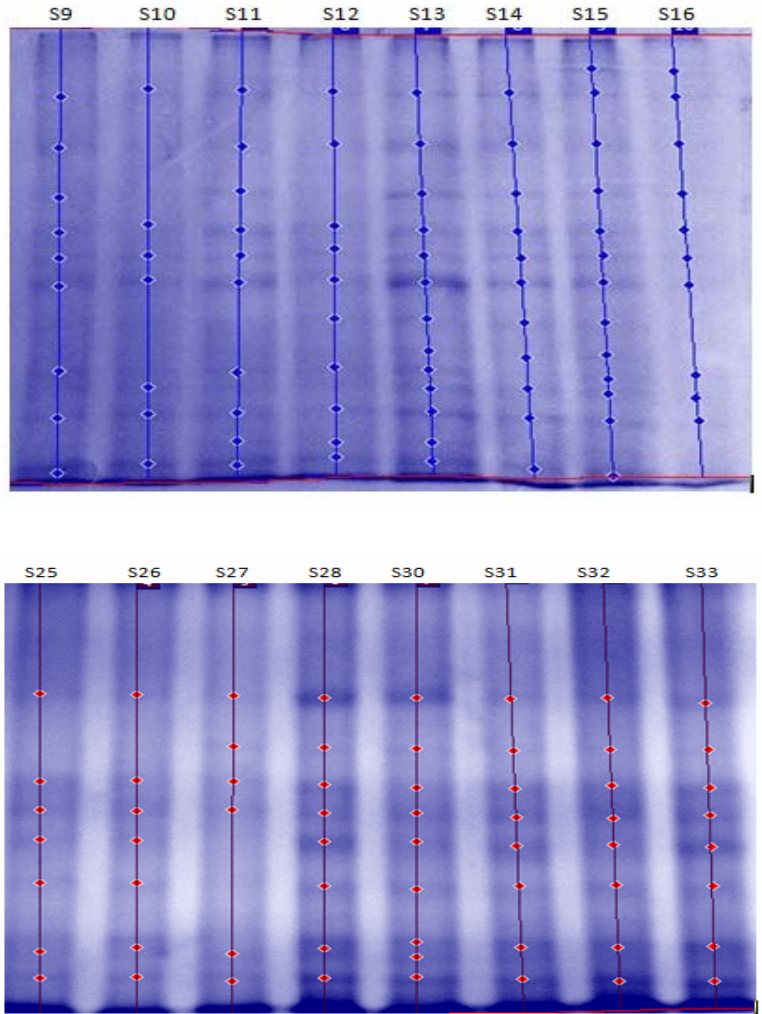

Figure 2. SDS-PAGE in leaf tissues of 40

new genotypes of sugarcane generated from open pollination of EH 26 - 2 parent 


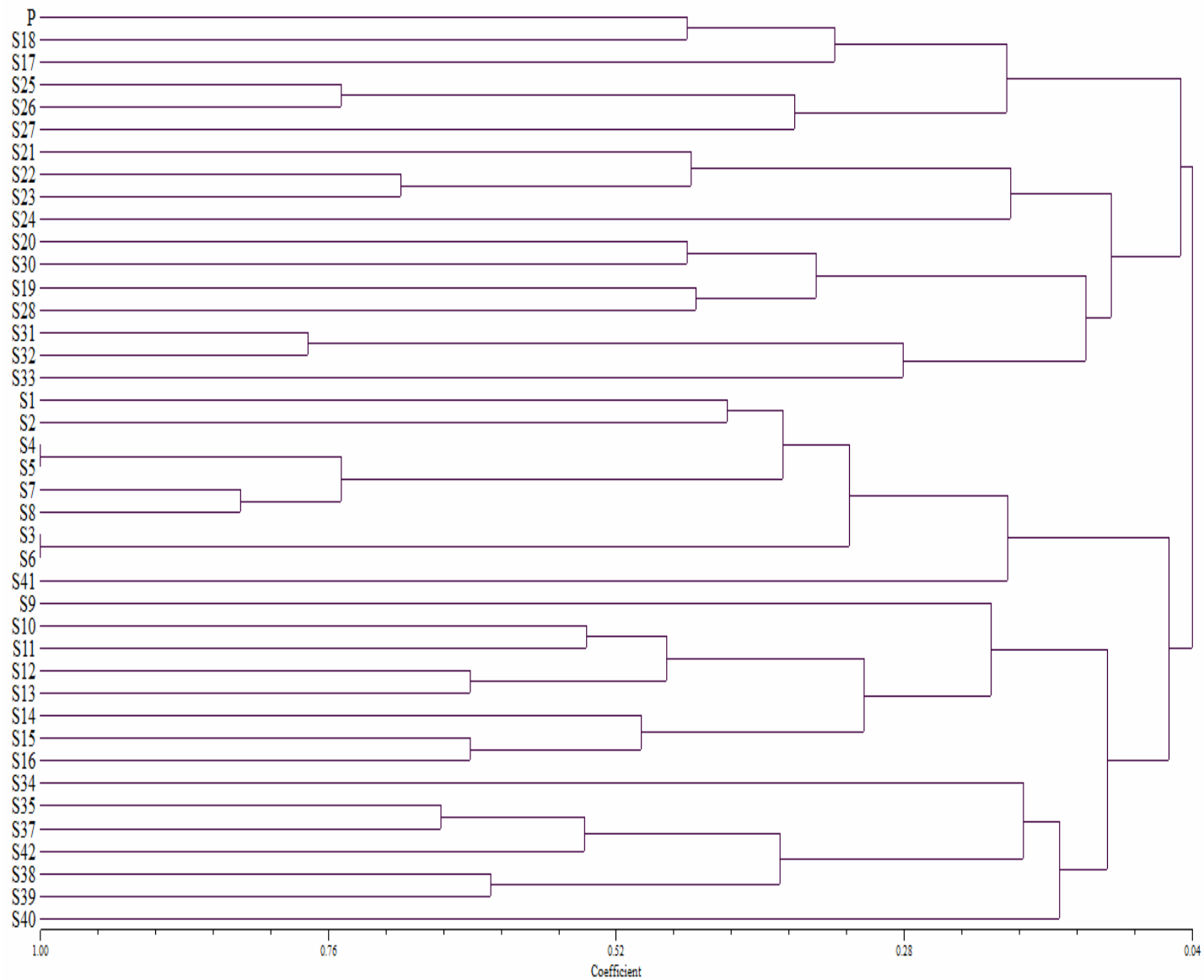

Figure 3. Dendrogram of cluster analysis based on total soluble protein electrophoretic fractions of leaf tissues of 40 new genotypes of sugarcane generated from open pollination of EH 26-2 parent

\section{Phylogenetic analysis}

The analyses of phylogenetic relationships among total soluble protein patterns of 40 sugarcane genotypes were presented in Figure 3. Cluster patterns of the 40 genotypes, elucidated by protein electrophoresis showed a wide range of total protein variants. The bands deduced by protein staining and matching genotypes of similar banding patterns in different genotypes. Pattern differences between band frequencies were a reflection of genetic distance between pairs of genotypes.

Stomata features play an important role in transpiration of water and gas exchange. The size and number of stomata determined the ability of the plant to lose or retain moisture. Reduced stomata length and width, and number per unit area are characteristics of plant tolerance to drought (Rai, 1999). Despite the differences of stomata measurements shown in Table 1, which showed that the tested genotypes were not significantly differ from the mother plant (M) that known as drought tolerant (Badawy et al., 2006).

\section{Assessment of leaf physiological parameters}

At the age of 180-days-old, the leaves were collected for physiological characteristics of the eleven selected genotypes and were evaluated for plant response to drought. Table 1, showed the differences of physiological profiles of the genotypes, reflecting their response to drought.

Stomata features play an important role in transpiration of water and gas exchange. The size and number of stomata determined the ability of the plant to lose or retain moisture. Reduced stomata length and width, and number per unit area are characteristics of plant tolerance to drought (Rai, 1999). Despite the differences of stomata measurements shown in Table 1, the analysis showed that the tested genotypes were not significantly differ from the mother plant $(\mathrm{M})$ that is known to be drought tolerant(Badawy et al., 2006). 


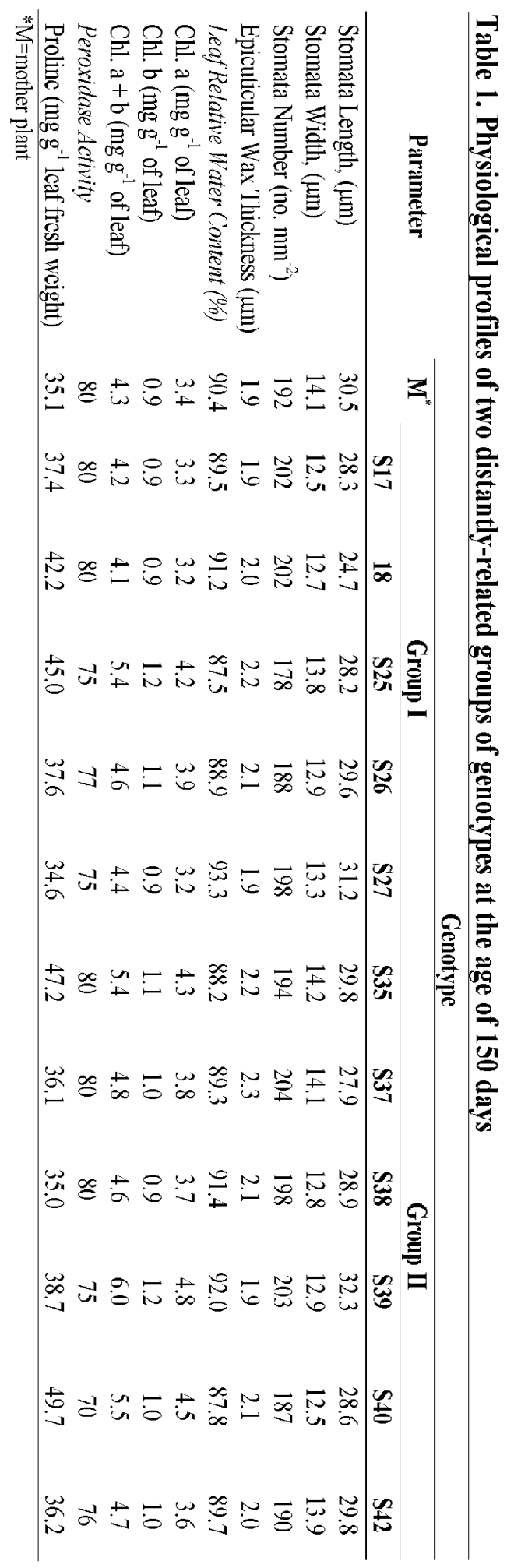


Epicuticular Wax Thickness (EWT) of all tested genotypes were thicker than that on the leaves of the mother plant; except genotypes S17, S27 and S39, which were equal to that of the mother plant. Thicker leaf epicuticular reduces water loss (Rai, 1999). Leaf relative water content (RWC) varied among genotypes, where RWC was lower in all genotypes compared with the mother genotype; except genotypes S18, S27, S38 and S39. Higher total leaf chlorophyll content (CC) is an indicator of a more efficient photosynthetic capacity of a plant genotype. It was higher in all genotypes compared with the mother genotype; except genotypes S17 and S18. Low Peroxidase activity (PA) is a characteristic of tolerance to drought (Eksomtramage et al., 1992). It was lower in all genotypes compared with the mother genotype; except genotypes S17, S18, S35, S37 and S38. There is a strong association between Proline content (PC) and tolerance to drought in sugarcane, where high leaf PC occurs in genotypes more tolerant to drought (Jagtap et al., 1988). It was shown that accumulation of free proline was greater in drought tolerant than sensitive genotypes, while greater accumulation was found in the leaves of 30-day than in older plant (Mu-Qing and R-Kai, 1998 and Jagtap et al., 1988). It was higher in all genotypes compared with the mother genotype; except S27 genotype.

\section{CONCLUSION}

Proteomic analysis of total soluble protein in leaf tissue extracts involving quantitative analysis, electrophoresis separation of proteins, dendrogram analysis and physiological profiling of genotypes allowed for identifying eleven diverse and distantlyrelated potential sugarcane genotypes, among them two distantly-related genotypes S25 and S40 would be of potential future varieties, and the eleven genotypes may be useful parents in future sugarcane breeding programs in crosses to identify hybrids with high specific combining ability.

\section{REFERENCES}

Allam, A.I., A.H. Nour and T.A. Fayed. 1977. The flowering behavior of latitudinally displaced sugarcane varieties. Proc. ISSCT, $1 b$.

Amalraj, R.S., N. Selvaraj, G.K. Veluswamy, R.P. Ramanujan, R. Muthurajan, Palaniyandi M., G.K. Agrawal, R. Rakwal. and R. Viswanathanl. 2010. Sugarcane proteomics: establishment of a protein extraction method for 2-DE in stalk tissues and initiation of sugarcane proteome reference map. Electrophoresis, 31:1959-1974.

Badawy, O. M., M. Z. Attallah and M. K. h. El- sh. 2006. Agro- physiological screening of sugarance genotypes for drought tolerance in northern Egypt. Alex. J. Agric. Res., 51(2): 133-145.
Bates, L.S., R.P. Waldern and I.D. Teare. 1973. Rapid determination of free proline for water-stress studies .Short communication. Plant and Soil 39:205-207.

Bradford, M.M. 1976. A rapid and sensitive method for the quantitation of microgram quantities of protein utilizing the principle of protein dye-binding. Anal. Biochem., 38: 248-252.

Capellades, M., R. Fontarnau, C. Carulla, and P. Debergh. 1990. Environmentinfluences anatomy of stomata and epidermal cells in tissue-cultured Rosa multiflora. Journal Amer. Soc. Hort. Sci. 115(1):141-145.

Davis, B. J. (1964). Disc electrophoresis. II. Method and application to human serum proteins. Annals of the New York Academy of Sciences 121: 404-427.

Eksomtramage, T., F. Paulet, J.L. Noyer, P. Feldmann and J.C. Glaszmann. 1992. Utility of isozymes in sugarcane breeding. Sugarcane, 3: 14-21.

Glaszmann, J.C. (1989). Proteomic genetic markers in sugarcane. Theor. Appl. Genet., 78: 537-543.

Hames, B.D. and D. Rickwood. 1990. Gel Electrophoresis of Nucleic Acids. A Practical Approach, 2nd ed. Oxford: IRL Press.

Jagtap, R.A., P.N. Tawar, D.R. Sen, N.M. Pant and D.G. Hapase. 1988. Effect of water stress on rate of transpiration and proline content in leaves of six varieties of sugarcane (Saccharum officinarum). 38th Decan Sugar Technologists Association, Annual Convention, 207216.

Karakas B., A.P. Ozias, C. Stushnhoff, M. Suefferheld and M. Rieger. 1997. Salinity and drought tolerance of mannitolaccumulating transgenic tobacco. Plant Cell and Environment, 20: 609-616.

Menéndez-Yuffa, A., E. de Garcia and M. Segura-Nieto. 1994. Comparative study of protein electrophoretic patterns during embryogenesis in Coffea arabica cv Catimor. Plant Cell Rep., 13: 197-202.

Mu Qing, Z. and C. Ru-Kai. 1998. Osmotic adjustment in lives of sugarcane in response to water stress. Sugar Cane, 5: 3-7.

Park, O.K. 2004. Proteomic studies in plants. J Biochem Mol Biol., 37(1): 133-138.

Rai, R.K. 1999. Variation of epicuticular wax content in sugarcane varieties and four species of Saccharum: a possible significance. Cooperative Sugar, 30(10): 955957.

Ramagopal, S. 1990. Protein polymorphism in sugarcane revealed by two-dimensional gel analysis. Theor Appl Genet, 79(3): 297-304.

Sambrook, J., E.F. Fritschi and T. Maniatis. 1989. Molecular cloning: a laboratorymanual, Cold Spring Harbor Laboratory Press, New York. 
Shewry, P.R., C. Brennan, A.S. Tatham, T. Warburton, R. Fido, D. Smith, D. Griggs, I. Cantrell, and N. Harris. 1996. The development, structure and composition of the barley grain in relation to its end use properties. In: Cereals 96. Proceedings of the 46th Australian Cereal Chemistry Conference, Sydney, September 1996, 158162.

Srivastava, H.M. 1993. Sugarcane breeding and varietal improvement in subtropical India. Sugarcane Research and Development in Sub-tropical India (eds.) G.B. Singh and O.K. Sinha, IISR, Lucknow, p. 37-75.

Sugiharto, B., N. Ermawati, H. Mori, and H. Sakakibara. 2002. Identification and characterization of a gene encoding drought-inducible protein localizing in the bundle sheath cell of sugarcane. Plant and Cell Physiology, 43(3): 350-354.
Wagih, E.E. and J. Fletcher. 1988. Electrophoretic and zymogram analysis of the cytoplasmic soluble protein fraction of Spiroplasma citri. Can. J. Microbiol., 34: 881885.

Wagih, M.E., A. Ala, O.M. Badawy and Y. Musa. 2005. Comparative Physiological Analysis of Selected Varietal Clones of Sugarcane in relation to Water Stress. Proc. International Conference on: "Political, Economic and Technical Challenges for Sugar and its Integrated Industries in the Arab Region, Middle East and the European Union, 3-4 April 2005, Palestine International Hotel, Alexandria, Egypt, pp 1-16.

Wagih, M.E. and E.E. Wagih. 1997. The Zymoblot technique: Potential in Ag-Biotechnology. Proc. Indonesian Biotechnology Conference, IPB, Jakarta, Indonesia, 12-20 June 1997.

Yadav, R.L. and R.I. Pasad. 1988. Moisture use characteristics of sugarcane genotypes under different available soil moisture regimes in alluvial lentisols. Journal of Agric. Sci. Coimbatore 1: 5-11. 


\section{الملغص العري}

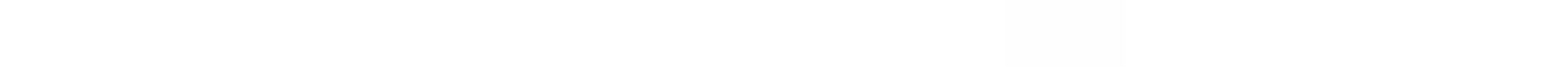

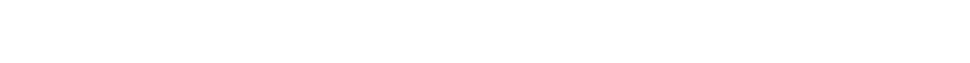

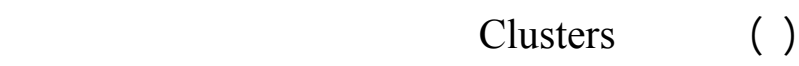

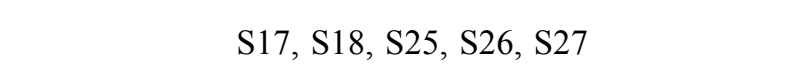

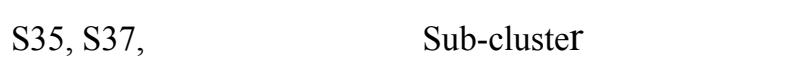

. S38, S39, S40, S42

وقم ققيم الصفات الفسيولوجية عند عمر ·1 ا يوم للأوراق

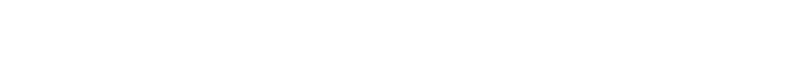

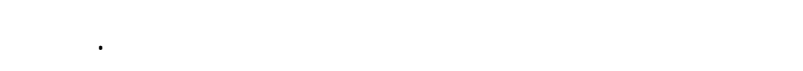

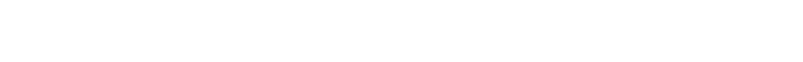

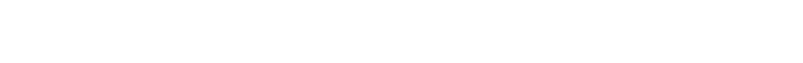

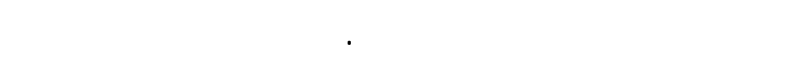
والمحتوى النسب ون البروتين والتي أظلهرت أن اللسلالتين

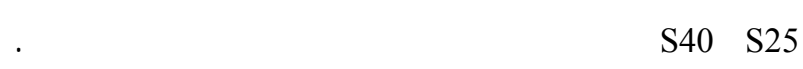

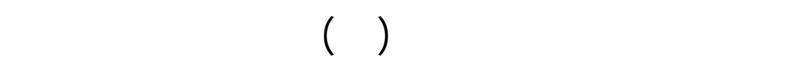

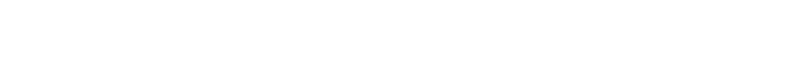
خاصة عالية على الخط.

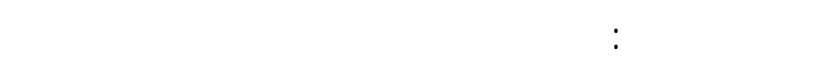

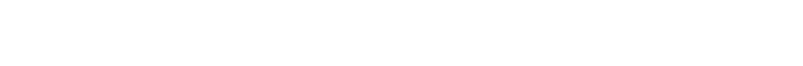
الانزيملت، قصب السكر، الشطط الأنزيمي.
مق انتخلب عدد rعسلالة جيية من قصب للسكر ناتجة من

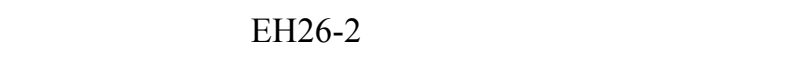

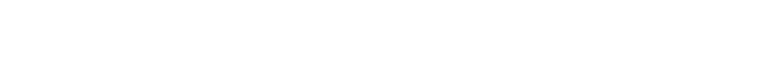

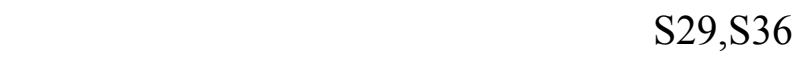

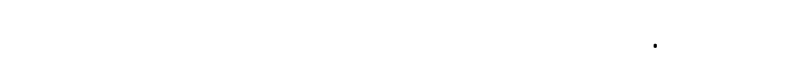

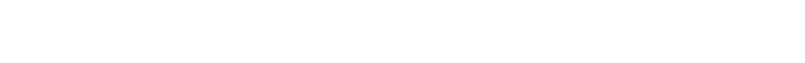

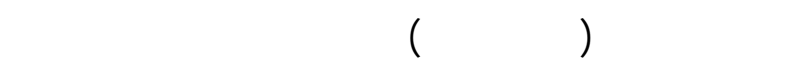

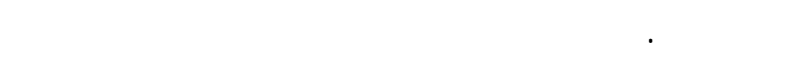
الوراثية في محتوى البروتين الكلي الذائب والتي تراوح تات بين

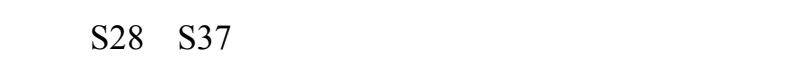

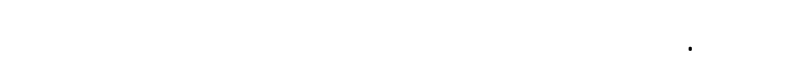

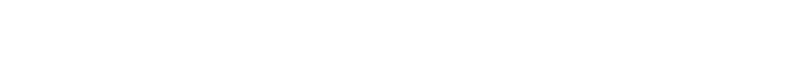
عليه مفردا كدليل حقيق لقيم الترليميب الوراثية. تحليل الهجرة الكهربية للبروتين بلستخدلم SDS-PAGE

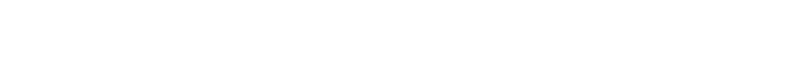

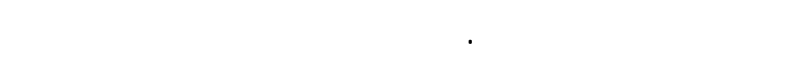

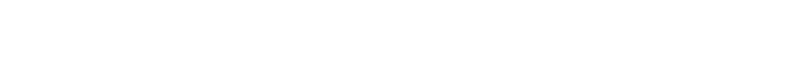
من الاختلافلت الفظهرية في البروتين. وقد مـ تمييز ع عدد 